\title{
2.3. \\ Transformacja ról i umiejętności menedżera
}

\section{Wprowadzenie}

Pojęcie roli menedżera ${ }^{45}$ i jego charakterystyka zajmuje kluczową pozycję w opracowaniach naukowych poświęconych analizie zachowań ludzi w organizacjach. Z uwagi na społeczny charakter relacji między ludźmi i formy, w jakich relacje te występują, rola ta obok roli społecznej ma decydujące miejsce $w$ opisie funkcjonowania zachowań organizacyjnych. Rozważania na ten temat eksponowane są szeroko w literaturze, prezentującej zbiór różnorodnych wymagań i oczekiwań w procesie realizacji roli kierowniczej. Jest ona także przedstawiana jako pojęcie złożone $\mathrm{i}$ trudne do jednoznacznego zdefiniowania bez uwzględniania jej społecznego, psychologicznego i organizacyjnego kontekstu. Rola kierownicza jest także najczęściej opisywana za pomoca funkcji lub cech sylwetki osób, które rolę tę odgrywają lub mogą odgrywać w strukturach hierarchii organizacyjnej [Błaszczyk 1999, s. 73]. Istnieje także duża zmienność układu pełnionych ról i możliwość występowania form pośrednich pomiędzy poszczególnymi typami, na które mogą składać się role cząstkowe.

W dążeniu do integracji tych ról zasadne wydaje się ich przedstawienie z perspektywy organizacji: tradycyjnej, współczesnej i przyszłej. Zaprezentowana $\mathrm{w}$ ten sposób poniższa charakterystyka roli i umiejętności menedżera ma przede wszystkim uwypuklić ich reprezentatywność oraz wyeksponować podstawowe orientacje typowe dla danego okresu, w którym funkcjonowała określona organizacja. Nie można również zapomnieć, że przedstawione role kierownika organizacji tradycyjnej, współczesnej i jutra nie są ograniczone horyzontem czasowym. Znaczy to, że cechy roli kierownika tradycyjnego mogą być również przypisywane współcześnie osobom zarządzającym np. organizacjami publicznymi, które charakteryzują się przede wszystkim

\footnotetext{
${ }^{45}$ Autorka w niniejszym tekście przedstawiając pracę kierownika, pomimo odmienności zakresowych tych pojęć, będzie posługiwała się zamiennie formą "kierownik”, „menedżer” lub „kadra kierownicza”. Szerzej: U. Ornarowicz, Menedżer XXI wieku. Definicja. Identyfikacja. Edukacja, Wydawnictwo Szkoły Głównej Handlowej, Warszawa 2008, s. 15-20.
} 
strukturą hierarchiczną i zasadami odnoszącymi do organizacji tradycyjnych.

\section{Spojrzenie na rolę $i$ umiejętności kierownika w organizacji tradycyjnej $^{46}$}

Zainteresowanie rolą kierownika $w$ organizacji zostało spowodowane pojawieniem się na przełomie XIX i XX w. nowych zagadnień organizacyjnych związanych $\mathrm{z}$ nowymi pod względem technologicznym sposobami pracy, zastosowaniem nowych narzędzi i koniecznością grupowania pracowników w organizacjach (fabrykach) zwiększających swoje rozmiary [Zieleniewski 1976, s. 54-55]. Od tego czasu wyodrębnia się charakterystyczne okresy, odpowiadające aktualnym wymaganiom i oczekiwaniom stawianym kierownikom. W pierwszym okresie, pod koniec XIX w., zwanym orientacja przedsiębiorcza, organizacje funkcjonowały w stabilnym otoczeniu, a zarządzanie nimi oparte było na doświadczeniu i intuicji kierowniczej. Wymagania wobec tych kierowników były niewielkie $\mathrm{i}$ wynikały $\mathrm{z}$ przeświadczenia, że nabyta wiedza i umiejętności są $\mathrm{W}$ pełni wystarczające do kierowania organizacją [Stańczyk-Hugiet 2010, s. 679]. Sytuacja zmieniła się pod wpływem rewolucji przemysłowej w pierwszej połowie XX w. Dynamiczny rozwój tego okresu, względnie homogeniczne warunki funkcjonowania otoczenia, stabilność na rynkach zaopatrzenia i sprzedaży, proste technologie, rynek producenta oraz niewielkie nasycenie wysoko wykwalifikowaną siłą roboczą [Sikorski 1999, s. 57] to podłoże sprzyjające dominacji organizacji tradycyjnych, czyli charakteryzujących się strukturami hierarchicznymi. Początek XX w. to także okres orientacji marketingowej, która wykształciła się w wyniku coraz bardziej różnicujących się rynków w skali krajowej i międzynarodowej [Stańczyk-Hugiet 2010, s. 679]. Oprócz tego na rolę ówczesnego kierownika wpłynęły takie siły, jak: przyspieszenie tempa pracy, wzrost wydajności i produktywności oraz intensywny rozwój industrializacji. Rola ta była jednak zazwyczaj omawiana pod względem treści, to znaczy opisywana za pomocą określonego zestawu działań lub funkcji. W tym kontekście role były w większości objęte funkcjonalna koncepcją zainicjowaną przez H. Fayola oraz interakcyjnym podejściem,

\footnotetext{
46 Ze względu na ograniczoną objętość opracowania autorka zdecydowała o przedstawieniu tylko typowych zachowań, specyficznych dla roli kierownika w organizacji tradycyjnej, nie negując przy tym wpływu szkół i podejść na sposób pełnienia roli kierownika w omawianym okresie.
} 
spopularyzowanym przez H. Mintzberga [Desmarais, Abord de Chatillon 2010, s. 74].

We wspomnianym okresie dominowało przekonanie o całkowitej asymetrycznej relacji między przełożonym a podwładnym. Przełożony umiejscowiony był zawsze w centrum działania, natomiast podwładni traktowani byli instrumentalnie, jako narzędzie do realizacji celów [Sikorski 1999, s. 84]. Rolą pracowników było wypełniać rozkazy kierownika, ignorując przy tym społeczne i psychologiczne aspekty ludzkiego zachowania. Także takie mechanistyczne działanie kierownika prowadziło do niechęci wobec zmian w środowisku organizacji [Almashaqba, Nemer Al-Qeed 2010, s. 64]. Kierownik stawał się głównie specjalistą posiadającym wiedzę i umiejętności potrzebne do funkcjonowania w warunkach konkurencji, zaś wymóg uwzględnienia zewnettrznego środowiska powodował, że od kierownika oczekiwano przede wszystkim myślenia w kontekście problemów ogólnych [Stańczyk-Hugiet 2010, s. 679].

Rola kierownika w organizacji tradycyjnej związana była również ze sprawną umiejętnością organizacji pracy podwładnych. Wynikało to z przekonania, że pracownicy nie posiadają zdolności do zorganizowania sobie pracy W sposób zapewniający maksimum wydajności oraz gwarantujący minimalizację wysiłku wkładanego w wykonywanie tej pracy [Koźmiński 1977, s. 82]. Kierownik musiał najpierw opracować optymalny wzorzec pracy dla każdego podległego stanowiska, a następnie wdrożyć go pracownikowi poprzez utrwalenie nawyków związanych z tym stanowiskiem [Koźmiński 1977, s. 83].

Ważnym obowiązkiem (a może pożądaną umiejętnością) nakładanym wyłącznie na kierowników był sposób radzenia sobie $\mathrm{z}$ niepewnością. $\mathrm{Z}$ tego względu akceptowany był możliwie jak najszerszy zakres władzy organizacyjnej każdego kierownika [Sikorski 1999, s. 106]. Od pracowników oczekiwano biernego podporządkowania, braku negacji decyzji kierownika i przystosowania do jego nałożonych zachowań. Zwiększony zakres władzy organizacyjnej kierownika przejawiał się także w jego wzmożonej ingerencji w sferę pozazawodową pracowników, przyczyniając się do ich częściowego ubezwłasnowolnienia. Zjawisko to (paternalizm) jest jednak dość często zdaniem Cz. Sikorskiego oczekiwane przez pracowników, którzy pragnąc zainteresowania ze strony przełożonego, zwiększają poprzez takie działania $\mathrm{w}$ miejscu pracy poczucie własnego bezpieczeństwa [Sikorski 1999 , s. 106]. Podporządkowanie i posłuszeństwo pracowników w organizacji koresponduje również z tzw. asymetryczną koncepcją władzy [Sikorski 2009, s. 40]. Zgodnie z tą koncepcją tylko kierownik 
potrafił sformułować właściwe cele działania danego zespołu i określić najlepsze sposoby ich realizacji. Kierownik miał być najlepszym specjalistą W zespole, ponosić wyłączną odpowiedzialność za podejmowane decyzje oraz posiadać umiejętność selekcjonowania informacji przekazywanych podwładnym [Sikorski 2009, s. 41]. Umiejętność ta związana była $\mathrm{z}$ redukcją niepewności wśród podwładnych i jej absorpcją przez kierownika. W ten sposób pozwalał on podwładnym ,tkwić w złudnym przekonaniu, że wszystko idzie jak najlepiej i nie ma podstaw do niepokoju" [Sikorski 1999, s. 108]. W tej sytuacji nawet gdy w organizacji doszło do kryzysu, podwładni nie byli o nim informowani, a wręcz przeciwnie, kierownictwo zapewniało o jej dobrej kondycji. Służyło to minimalizowaniu wszelkich zjawisk patologicznych, mogących szerzyć się w organizacji, np. strajków czy manifestacji. Z drugiej jednak strony, taka selekcja informacji stwarzała iluzję bezpiecznego środowiska pracy.

Bierne wykonawstwo pracowników sprzyjało również realizowaniu przez kierownika rozbudowanych formalnych i nieformalnych komórek kontrolnych [Koźmiński 1977, s. 92]. Miały one na celu wywołać poczucie stałego zagrożenia różnorodnymi sankcjami w przypadku nieprawidłowego wykonania polecenia wykrytego przez przełożonego [Koźmiński 1977, s. 92]. Rola kierownika ukierunkowana była zatem na wzmocnienie aparatu kontroli.

Do obowiązków kierownika w organizacji tradycyjnej zaliczano przede wszystkim: świadome przyswajanie całej praktycznej wiedzy posiadanej przez pracowników wykonujących różne czynności w danej organizacji, umiejętny dobór pracowników i stopniowe rozwijanie ich zdolności w procesie pracy poprzez szkolenia, wdrożenie pracownikom naukowej wiedzy oraz realizację części zadań wykonywanych przez podwładnych mających na celu równy podział pracy [Taylor, cyt. za Kurnal 1972, s. 64-67].

Autorytet kierownika wynikał natomiast $\mathrm{z}$ zajmowanego stanowiska, a nie $\mathrm{z}$ racji posiadanych kwalifikacji. To właśnie autorytet formalny i władza stanowiły punkt wyjścia do opisu ról kierowniczych w organizacji. Pionierem w ich badaniu był H. Mintzberg, który rolę kierowniczą określił jako funkcję wypełnianą przez kierowników w kontekście określonej hierarchii organizacyjnej, definiując ją jako „zorganizowany zbiór zachowań” [Mintzberg 1975 cyt. za: Kaczmarek, Sikorski 1999, s. 46]. Opisując pracę kierowniczą i wymagania, jakie stawia się tym, którzy ją wykonują, H. Mintzberg wyodrębnił dziesięć podstawowych ról, które zaliczył do trzech kategorii: interpersonalne, informacyjne i decyzyjne [Schermerhorn 2008, s. 33]. Pierwsze z nich - 
interpersonalne (reprezentacyjna, przywódcza, łącznik) oznaczają kontakty $\mathrm{z}$ innymi ludźmi wewnątrz $i$ na zewnątrz środowiska organizacji, role informacyjne (obserwator, propagator informacji, rzecznik) mają na celu odbieranie i analizowanie informacji oraz ich przetwarzanie i przekazywanie innym pracownikom organizacji, zaś role decyzyjne (negocjator, przeciwdziałający zakłóceniom, dysponent zasobów) odnoszą się do procesu podejmowania decyzji w organizacji [Griffin 2004, s. 18-19]. H. Mintzberg doszedł również do wniosku, że kierownicy postępują podobnie na wszystkich szczeblach zarządzania $\mathrm{w}$ strukturze organizacyjnej. Związane jest to $\mathrm{z}$ tym, że mają formalna władzę nad podporządkowanymi im zespołami pracowniczymi, a ich pozycja $w$ hierarchii wewnątrz organizacji wynika właśnie $\mathrm{z}$ tej władzy. To powoduje, że wszyscy kierownicy wchodzą w relacje międzyludzkie z podwładnymi, kolegami, przełożonymi, otrzymując od tych grup informacje, na podstawie których mogą podejmować decyzje [Kaczmarek, Sikorski 1999, s. 46]. Zaproponowane przez H. Mintzberga role stanowią punkt wyjścia do innych klasyfikacji ról.

Zdaniem B. Dumaine kierownik w organizacji tradycyjnej postrzegał siebie bardziej jako szefa, większość decyzji podejmował samodzielnie, był kierownikiem funkcjonalnym wyspecjalizowanym najczęściej w jednej dziedzinie, np. w marketingu czy finansach, pracował $\mathrm{w}$ ramach ustalonej struktury organizacyjnej oraz był „skarbnica informacji”, „trzymając je” w tajemnicy [Dumaine 1993, s. 80-84].

Z kolei A. Stosik do klasycznych ról kierownika zalicza nadawcę, wizjonera i stratega [Stosik 2005, s. 522].

J. Szaban uważa natomiast, że choć w przeszłości kierownik był bardziej administratorem i wykonawca, to zawsze silnie identyfikował się $\mathrm{z}$ własną organizacja, mając przy tym wysokie poczucie odpowiedzialności za to, co się z nią dzieje [Szaban 2000, s. 224]. W tym kontekście, posługując się metafora, kierownika w organizacji tradycyjnej można było porównać do kapitana statku. Podobnie jak on charakteryzował się dużą odpowiedzialnością za kierowaną jednostkę, którą opuszcza dopiero po wykorzystaniu wszelkich możliwości i sposobów naprawczych.

Inaczej rolę kierownika ukazuje W. Kieżun. Choć jego koncepcja odnosi się do kierowników przedsiębiorstw socjalistycznych, to zyskała także uznanie w gospodarce rynkowej. W koncepcji tej przyjmuje się, że kierownik był przede wszystkim organizatorem procesów pracy, opiekunem i wychowawcą załogi, a także organizatorem określonej polityki [Kieżun 1997, s. 189-190]. 
Zdaniem J. Biedy klasyczne role kierownika sprowadzają się do komenderowania, kontrolowania i korygowania, których celem było zapewnienie norm i porządku oraz odpowiedniej wydajności [Bieda 2004, s. 157].

C. P. Hales omawiając pracę kierownika organizacji tradycyjnej, stwierdził, że do charakterystycznych cech jego roli należało: specjalistyczne i zawodowe wykształcenie kierownicze, odpowiedzialność za procesy pracy (przy czym charakter pracy obejmował różne elementy, czas trwania i zasoby), rozwiązywanie problemów ogólnych i doraźnych, elementów, czasu trwania i zasobów, komunikowanie się w sposób formalny, systematyczne formułowanie planów, spędzanie większości czasu na nieformalnych relacjach, rozwiązywanie konfliktów społecznych oraz podejmowanie negocjacji [Hales 1986, s. 104, cyt. za Akella 2006, s. 222].

Zaprezentowane powyżej cechy roli odnoszone do pracy kierownika nie są jedynymi i nie stanowią zamkniętego zbioru. Jednakże biorąc pod uwage wcześniejsze rozważania na temat roli kierownika $\mathrm{w}$ organizacji tradycyjnej, można uznać, że charakterystyczne są: rola dyrektora, nakazującego, nadzorcy oraz kontrolera. Są to te role, których realizacja jest konieczna, aby sprostać wymaganiom i oczekiwaniom środowiska organizacji tradycyjnej.

Oprócz wypełniania ról w organizacji kierownicy muszą również posiadać określone umiejętności, po raz pierwszy zidentyfikowane przez R. L. Katza. Wyróżnił on trzy podstawowe umiejętności: techniczne (technical skill), społeczne (human skill) i koncepcyjne (conceptual skill) [Katz 1955, s. 38]. Proporcje tych umiejętności są różne, zależne od szczebla zarządzania. Na niższym szczeblu najbardziej pożądane są umiejętności techniczne, które związane są ze specyfiką danej organizacji. Są to procesy, procedury, metody, techniki i narzędzia pracy, które pozwalają na wykonanie zadań w danej organizacji. Na wyższym poziomie wzrasta ranga umiejętności koncepcyjnych, niezbędnych do holistycznego i abstrakcyjnego myślenia o organizacji oraz jej dalszych kierunkach działania [por. Katz 1955]. To właśnie, zdaniem R. L. Katza, brak tych ostatnich umiejętności u naczelnego kierownictwa może przyczynić się do zagrożenia sukcesu całej organizacji [Katz 1955, s. 38]. Natomiast umiejętności społeczne są to zdolności w nawiązywaniu kontaktów ze środowiskiem zewnętrznym i wewnętrznym organizacji, w takim samym stopniu potrzebne na każdym szczeblu zarządzania. Z czasem przytoczony wyżej podział został uzupełniony o nowe elementy, np.: umiejętności diagnostyczne, czyli „zdolności menedżera 
do wyobrażenia sobie najwłaściwszej reakcji w danej sytuacji" [Griffin 2004, s. 21].

Biorąc jednak pod uwage pracę kierownika organizacji tradycyjnej, wydaje się, że do preferowanych umiejętności należały: umiejętności organizowania pracy podwładnym, egzekwowania wydanych poleceń, formułowania celów oraz redukcji niepewności wśród pracowników. Wskazane zaś umiejętności w sposób wystarczający prowadziły do osiagania założonych wyników w organizacji tradycyjnej.

Z czasem okazało się, że wdrożone zasady, które kiedyś były w stanie zwiększyć wydajność organizacji, są nieodpowiednie do społecznych i psychologicznych potrzeb pracowników i osiagają odwrotny skutek [Almashaqba, Nemer Al-Qeed 2010, s. 65]. Wraz z rozwojem technologii informacyjnej, odchodzeniem od nieelastycznych struktur zarządzania na rzecz elastyczności, dostrzeganiem roli jednostki i jej kapitału w tworzeniu wartości organizacyjnych zaczynają formować się nowe role, które przypisuje się menedżerom organizacji współczesnej.

\section{Współczesne role i umiejętności menedżera}

Pod koniec XX w. nastapiły istotne zmiany w sferze organizacji pracy, spowodowane przez globalizację, integrację europejska, zwiększoną konsumpcję, wzrost znaczenia wiedzy i informacji oraz dostrzeżenie, że psychospołeczne oddziaływanie na pracownika przyczynia się $\mathrm{W}$ większej mierze do wydajności jego pracy [Almashaqba, Nemer Al-Qeed 2010, s. 64-65]. Współczesna organizacja nastawiona jest przede wszystkim na atomizację i twórczość jednostek, oczekując przy tym dużego zaangażowania organizacyjnego. Stanowi to siłę tej organizacji, która zaczęła kreować nowe warunki pracy. Także w latach 80 . wiele amerykańskich organizacji rozpoczęło poszukiwanie nowych recept na sukces. Wynikało to $\mathrm{z}$ ich trudnej sytuacji i coraz większych wymagań stawianych ówczesnym menedżerom zarówno pod względem jakościowym, jak i ilościowym [Rakowska 2007, s. 38]. To przyczyniło się do podjęcia dyskusji na temat roli menedżera w organizacji współczesnej ${ }^{47}$. W tym miejscu należy podkreślić, że ze względu na różnorodność ról oraz ich zależność od rodzaju organizacji czy zajmowanego miejsca w hierarchii organizacyjnej, w praktyce trudno jest ustalić sztywne bariery pomiędzy nimi. W rzeczywistości bowiem, biorąc pod uwagę ciagły „ruch” wewnątrzorganizacyjny, poszczególne

\footnotetext{
47 Opisując pracę menedżera w organizacji współczesnej przyjęto za S. R. Quinnem, M. P. Faermanem i M. R. Thompsonem, że rozpoczyna się ona od 1976 r. (por. A. Rakowska 2007, s. 38).
} 
role kierownicze nie są odgrywane w ustalonej kolejności. Przeplatają się one, tworząc raczej sieć, w której funkcjonuje kadra kierownicza, chociaż sieć ta nie dla wszystkich jest jednakowa [Błaszczyk 1999, s. 82].

Współczesne organizacje wymagają od pracowników zwiększającego się zakresu samodzielności i odpowiedzialności za realizację zadań $\mathrm{w}$ organizacjach. Pracownicy zaś w sposób natychmiastowy rozwiązują pojawiające się problemy, gdyż menedżerowie zajmują się innymi sprawami związanymi z funkcjonowaniem organizacji [Sikorski 1999, s. 99]. Relacje między przełożonym a podwładnym stają się bardziej demokratyczne. Występuje tutaj zależność odwrotnie proporcjonalna. Im pracownik odznacza się lepszym wykształceniem i charakteryzuje większą inteligencją, tym mniej potrzebuje odgórnego kierowania. Ma on przy tym więcej swobody i odpowiedzialności [Sikorski 1999, s. 100], by móc rozwinąć swoje umiejętności i zdolności, co wpływa na wartość kapitału ludzkiego w organizacji.

Zmienia się zatem stosunek do władzy organizacyjnej. Współcześnie władza ta charakteryzuje się nietrwałością i przechodniością. Oznacza to, że kiedy zadanie zostanie zrealizowane, następuje ,przekazanie” władzy [Sikorski 1999, s. 101-102], co ma związek z empowermentem. Sa to „działania związane z dzieleniem się władzą $\mathrm{z}$ pracownikami-podwładnymi poprzez delegowanie odpowiedzialności, umożliwienie zaangażowania $\mathrm{W}$ ten proces, zachęcanie do autonomicznego działania i okazywanie wiary pracownikom $\mathrm{w}$ ich zdolność do zarządzania własną pracą" [Charbonnier-Voirin, El Akremi 2011, s. 125]. Dowodzenie i kontrolę zastępuje się zatem angażowaniem podwładnych $\mathrm{w}$ proces podejmowania decyzji i delegowania zadań [Bradford, Cohen 1984, s. 44]. Empowerment umożliwia pracownikom nie tylko uczestnictwo $\mathrm{w}$ procesie podejmowania decyzji, ale również $\mathrm{w}$ procesie zarządzania organizacją. Sprawia, że pracownik odczuwa większą satysfakcję z wykonywanej pracy, zwiększa się jego morale, ale przede wszystkim nie jest on traktowany jedynie jako „trybik” w procesie kierowania. Zwiększa się także obopólne zaufanie pomiędzy przełożonym a podwładnym, co wpływa na szybkość i jakość podejmowanych decyzji. Menedżer koncentruje się zaś na poszukiwaniu szans rozwojowych i innowacyjnych oraz stwarzaniu odpowiednich warunków dla funkcjonowania organizacji [Sikorski 1999, s. 100]. Do tych warunków można zaliczyć: zwiększanie elastyczności poszczególnych obszarów zasobowych, działania związane $\mathrm{z}$ budową i utrzymaniem przewagi konkurencyjnej, zapewnienie właściwego środowiska pracy oraz 
dostrzeganie szans w zmiennym otoczeniu, zwłaszcza w sytuacji zjawisk kryzysowych.

We współczesnym świecie mamy do czynienia z turbulentnymi zmianami i nieprzewidywalnym środowiskiem organizacyjnym, które staje się katalizatorem do realizowania przez menedżera - roli agenta zmiany (change agent). Umiejętności związane $\mathrm{z}$ tą rolą potrzebne są przede wszystkim w warunkach szybkich zmian, szczególnie w tych systemach, które nie reagują odpowiednio na pojawiające siły w zmieniającym się środowisku [Westover 2010, s. 45]. Zadaniem menedżera jako agenta zmiany jest tworzenie klimatu i odpowiednich warunków dla planowanej zmiany, mobilizowanie sił do pozytywnego jej wzrostu oraz przezwyciężanie oporów mogących pojawić się w tym procesie. To właśnie konsultowanie, informowanie i komunikowanie są tymi aspektami, które nabierają istotnego znaczenia podczas planowania i wdrażania zmian w organizacji. Współczesny menedżer to zatem osoba, która partycypuje $\mathrm{w}$ procesie zmian poprzez komunikowanie się i szkolenie, udzielanie pracownikom odpowiedniego wsparcia oraz ich stymulację do aktywnego uczestnictwa.

Ponieważ obecnie coraz większą wagę przywiązuje się do zarządzania procesowego jako koncepcji radykalnych przekształceń, menedżerowie organizacji współczesnej w większym stopniu stają się architektami procesów zachodzących w organizacji. W tym zakresie niezbędnymi umiejętnościami menedżera są spajanie wszystkich elementów (ludzi i działań) oraz dostrzeganie zachodzących wielostronnych zależności między nimi [Rakowska 2007, s. 52-53].

Współczesny menedżer to także przywódca. Jednakże nie jest to tradycyjne rozumienie przywództwa jako zdolności do wywierania wpływu na inną jednostkę, lecz zmierza ono w kierunku przywództwa służebnego. Jest to konsekwencja, zdaniem Ch. Evans, podporządkowania organizacji - wiedzy [Evans 2005, s. 67]. Do atrybutów menedżera realizującego przywództwo służebne należy przede wszystkim: delegowanie uprawnień, bezwzględna uczciwość, głęboka wiedza, wizja i system wartości sprzyjające różnorodności oraz inspirowanie ludzi i organizacji do zmian [Evans 2005, s. 67]. Ma ono szczególne znaczenie $\mathrm{w}$ kreowaniu środowiska sprzyjającego pracy opartej na wiedzy, w którym centralną rolę odgrywa przywódca, nie w sensie przywilejów i korzyści, lecz zobowiązań wobec całości. Jest to zatem ten rodzaj przywództwa, które opiera się na zaufaniu oraz podporządkowaniu wiedzy i organizacji opartej na wiedzy, a nie odwrotnie [Grudzewski, Hejduk, Sankowska, Wańtuchowicz 2010, s. 144]. W tej sytuacji menedżer w roli przywódcy ma przewodzić 
ludziom, wyzwalać w nich energię, być nośnikiem wiedzy, kształtować relacje między pracownikami, w których wspólnym mianownikiem jest obopólne zaufanie, stanowiące podstawę współczesnego przywództwa.

W związku z pojawieniem się nowych form organizacyjnych, tzw. e-organizacji nastapiło zapotrzebowanie na inne role wypełniane przez menedżera. Dodatkowo jego praca kierownicza ukierunkowana jest na permanentny rozwój i utrzymywanie kontaktów $\mathrm{z}$ klientami, współpracownikami i przełożonymi, których integralną częścią stają się technologie informacyjne [Akella 2006, s. 238]. W takich warunkach funkcjonowania menedżer realizuje rolę e-menedżera. Zdaniem A. Rakowskiej rola ta jest bardziej elastyczna, dynamiczna i złożona, ponieważ menedżerom stawiane są wyższe wymagania intelektualne i osobowościowe oraz częściej określa się oczekiwane rezultaty niż konkretne zadania [Rakowska 2007, s. 44]. Menedżer zarządzający e-organizacją musi również pełnić funkcję przedsiębiorcy [Rakowska 2007, s. 45]. Do jego głównych umiejętności należą: wdrażanie innowacyjnych rozwiązań, inicjowanie zmian, działanie w ramach poszerzającego się zakresu zmian organizacji oraz umiejętne podejmowanie decyzji w warunkach ryzyka. Kierownik przedsiębiorczy to także dobry organizator działań i wykorzystujący w sposób umiejętny posiadane zasoby w celu maksymalizacji zysku zarządzanej organizacji.

Równocześnie obok roli menedżera przedsiębiorcy wyodrębnia się kreatywność. Podkreśla się, że ta cecha jest podstawowym nośnikiem nowych idei, inicjatyw i powstających koncepcji lub przesłanką do nowego spojrzenia na pomysły już istniejące [por. Błaszczyk 2004]. Kreatywny menedżer wpływa na rozwój współczesnego środowiska pracy, wspiera style przywódcze, stymuluje pracowników do dzielenia się wiedzą i pobudza ich do własnego rozwoju twórczości [Hon, Bloom, Crant 2011, s. 20]. Jego nowe pomysły wpływają na oryginalne i innowacyjne rozwiązania danego problemu. Menedżer - kreatywny i przedsiębiorczy nie tylko reaguje na zachodzące zmiany w otoczeniu, ale sam potrafi je wywołać oraz realizować w praktycznej działalności kierowniczej [Błaszczyk 2004, s. 67]. Kreatywność i przedsiębiorczość są zatem umieszczone $w$ strukturze cech sylwetki współczesnego kierownika i jego roli w organizacji [Penc 2005, s. 68] oraz mogą być źródłem sukcesu w pracy kierowniczej.

Współcześnie duże znaczenie w pracy kierowniczej przypisuje się roli profesjonalisty. Rola ta stanowi zbiór umiejętności pozwalających na samodzielne rozwiązywanie złożonych, nierutynowych problemów w danej dziedzinie, mających często charakter zadań eksperckich [Sikorski 1995, s. 15]. Profesjonalny menedżer to taki, który według 
M. Dąbek w wysokim stopniu opanował wymagania swojego zawodu w zakresie przypisywanych mu obowiązków oraz posiada wiedzę na temat zarządzania wraz z umiejętnościami [Dąbek 2002, s. 130]. W XXI w. to właśnie profesjonaliści stają się dominująca grupą $\mathrm{W}$ organizacji. Wymaganie to odnoszone jest do wszystkich typów organizacji. Coraz częściej podkreśla się, że szkołą czy szpitalem powinny zarządzać osoby przygotowane profesjonalnie do tego zawodu. Menedżer w roli profesjonalisty wykonuje swoją pracę według najwyższych standardów, działając przy tym na rzecz efektywności organizacji oraz przestrzegając jej kodeksu wartości. To właśnie te ostatnie są coraz częściej dostrzegane przez współczesne organizacje, które stają się drogowskazem dla decyzji i działań pracowników, zastępując szczegółowe procedury i przepisy [Świątek-Barylska 2010, s. 775]. Najbardziej jednak widocznym i najważniejszym przejawem wartości w wymiarze organizacyjnym jest zdaniem Cz. Zająca skuteczne przekładanie zawartych w misji strategii przedsiębiorstwa, kodeksów etycznych na sposób pełnienia ról menedżerskich. Dotyczy to przede wszystkim procesu podejmowania decyzji, przydziału zadań, nagradzania, kształtowania relacji interpersonalnych oraz komunikacji wewnątrzorganizacyjnej [Zając 2009, s. 1224]. Dlatego rolą menedżera organizacji współczesnej jest inicjowanie i propagowanie kluczowych wartości organizacyjnych [Świątek-Barylska 2010, s. 775]. Jest to istotne z punktu widzenia kształtowania proefektywnościowej kultury organizacyjnej, w której to właśnie wspólne wartości uczestników zajmują kluczowe i centralne miejsce $w$ organizacji.

W związku z dalszym umiędzynarodowieniem gospodarki i poszczególnych funkcji organizacji szczególnym wyzwaniem dla menedżerów staje się umiejętność funkcjonowania $\mathrm{w}$ różnorodnym otoczeniu. Treść roli współczesnego menedżera przekształca się w kierunku menedżera międzynarodowego. Wzrasta zapotrzebowanie na menedżerów umiejących działać na rynku globalnym, na którym coraz częściej zarysowują się nowe wymogi i zadania odnoszące się do międzynarodowej kadry menedżerskiej [por. Listwan, Stor 2008]. Należą do nich przede wszystkim: umiejętność pracy w zespołach międzynarodowych, znajomość nowych technologii telekomunikacyjnych, przewaga specjalizacji zadaniowej nad funkcjonalną, chęć poszukiwania nowych rozwiązań, otwartość na rzeczy nowe, gotowość uczenia się i dzielenia wiedzą, umiejętność analizowania środowiska korporacji wewnątrz- i zewnątrzorganizacyjnego [Stor 2010, s. 710-711]. Szczególnie istotne są również takie umiejętności, jak: znajomość języków obcych, nawiązywanie i podtrzymywanie kontaktów 
międzynarodowych, umiejętność pracy $\mathrm{w}$ różnorodnym środowisku, dostrzeganie $\mathrm{w}$ nim szans i nadarzających się okazji, nawiązywanie kontaktów, umiejętność poszukiwania i współpracy z kontrahentami w ramach wspólnego rynku, współpracy i integracji z ,różnorodnymi” pracownikami oraz zarządzania heterogenicznym personelem w środowisku wielokulturowym. Niezwykle istotne w pracy menedżera międzynarodowego są również szybkość uczenia się oraz umiejętność zarządzania emocjami, przydatne na skutek oddziaływania szoku kulturowego.

Umiejętności współczesnego menedżera to także te, które związane są z procesem doskonalenia zawodowego. Obejmuje ono nie tylko samego menedżera, ale również wszystkich pracowników. Wynika to $\mathrm{z}$ faktu, że wiek XXI utożsamiany jest $\mathrm{z}$ erą wiedzy i społeczeństwa informacyjnego. Nie wystarczy już zatem zakończyć edukację na etapie studiów wyższych, ponieważ istniejąca wiedza podwaja się z częstotliwością siedmiu lat, a połowa wiedzy, której uczą się studenci na pierwszym roku, jest już nieaktualna w momencie, gdy kończą ostatni etap nauki [Fazlagić 2001, s. 25]. W tym kontekście wydaje się, że zarządzający organizacją dostrzegają zjawisko „przeterminowania” wiedzy. Coraz chętniej menedżerowie uczestniczą w szkoleniach, nie zapominając również o swoich podwładnych. Wydaje się, że współcześni menedżerowie mają świadomość, że inwestycja w pracownika to inwestycja w organizację. Świadczy o tym badanie Eurofound, które wykazało, że europejskie firmy inwestują w szkolenia pracowników najwięcej od 15 lat. W 2010 r. w kursach, warsztatach czy treningach opłacanych przez pracodawcę uczestniczył co trzeci pracownik z krajów europejskich [www.hrtrendy.pl]. Także szkolenia są bardzo często elementem, który ma na celu zwiększyć przywiązanie i lojalność pracownika względem organizacji.

Proces doskonalenia zawodowego koresponduje także z mentoringiem i coachingiem jako nowe spojrzenie na relacje przełożony-podwładny. Takie podejście pomaga współczesnym menedżerom $\mathrm{w}$ tworzeniu wiedzy oraz wspieraniu procesów uczenia się w ramach organizacji [Akella 2006, s. 222]. Pierwsze z nich, mentoring to „intensywny związek pomiędzy starszym doświadczonym pracownikiem mający na celu zapewnienie wsparcia dla mniej doświadczonych kolegów zwanych podopiecznymi lub protegowanymi" [Hezlett, Gibson 2007, s. 385]. Ma on na celu opiekę nad nowo zatrudnionym pracownikiem, zapoznanie $\mathrm{z}$ kulturą organizacyjna, kształtowanie jego rozwoju zawodowego oraz pożądanych wzorców. Do głównych zalet mentoringu z perspektywy menedżera zalicza się: rozwój własny i podwładnych oraz 
usprawnienie procesu komunikacji w relacji przełożony-podwładny [Ehrich, Hansford 1997, s. 99]. Biorąc natomiast pod uwagę obecne trendy w miejscu pracy, takie jak: ponoszenie większej odpowiedzialności za pracowników, zarządzanie własną kariera, rosnące zapotrzebowanie na ciągłe uczenie się oraz doskonalenie szkoleń on-the-job, mentoring zdobywa i będzie zdobywać coraz większą popularność [Hezlett, Gibson 2005, s. 447].

Coaching zaś ułatwia intensywne i systematyczne szkolenie osób za pomocą różnorodnych technik behawioralnych i metod mogących pomóc $\mathrm{w}$ osiagnięciu samodzielnego rozwoju jednostki i celów organizacyjnych, prowadząc do poprawy efektywności organizacji [Segers, Vloeberghs, Henderickx, Inceoglu 2011, s. 204]. Menedżer w roli coacha ma zatem wspomagać pracownika na ścieżce kariery zawodowej poprzez rozwój jego talentów. Wyzwala przy tym jego poczucie kreatywności i otwartości na przyszłe wyzwania. Realizowanie tej roli przez menedżera świadczy w dużym stopniu o zaangażowaniu organizacji $\mathrm{w}$ upodmiotowienie pracownika, stawiając go $\mathrm{w}$ centrum zainteresowania, wpływając na jego identyfikację silnych i słabych stron, cele, dążenia i pożądane wartości organizacyjne.

Ponieważ współcześnie zasoby niematerialne stanowią podstawę funkcjonowania każdej organizacji i sprzyjają pracy opartej na wiedzy, eksponowana jest coraz częściej rola pracownika wiedzy. Taki pracownik według P. Druckera wykorzystuje wiedzę w pracy, posiada unikatowe kompetencje, dąży do mistrzostwa osobistego i zwiększa wartość organizacji [Drucker 1954, cyt. za: Mládková 2011, s. 826]. Odnoszona jest ona jednak nie tylko do pracowników wykonawczych, ale również do kadry kierowniczej. Choć w literaturze można dokonać kategoryzacji pracowników wiedzy, uszczegółowiając ich za pomocą wybranych cech [Morawski 2009, s. 90-93], to wydaje się, że podstawowe ich cele będa takie same. W tej sytuacji do celów menedżera wiedzy zalicza się „pozyskiwanie, tworzenie, uszlachetnianie i wykorzystywanie wiedzy i informacji. (...) Łączy on $\mathrm{w}$ działaniu wiedzę $\mathrm{z}$ różnych dziedzin, posiadając zarazem pogłębioną wiedzę specjalistyczną i oparte na niej konkretne, sprawdzone w praktyce, szczególne umiejętności, często niedostępne innym. Autorytet zawodowy pracownika wiedzy jest wypadkową wiedzy specjalistycznej, rozległych horyzontów poznawczych, mistrzowsko opanowanych umiejętności fachowych oraz wciąż rozwijanych umiejętności społecznych, pozwalających na elastyczne i bezpośrednie współdziałanie $z$ innymi pracownikami" [Morawski 2009, s. 45]. Menedżer wiedzy to zatem specjalista, dla którego, zdaniem M. Morawskiego, najważniejszym stają się procesy, 
utrwalające lub tworzące unikalne kompetencje organizacji, zaspokajające lub kreujące wciąż nowe potrzeby jej interesariuszy. Tacy menedżerowie w konsekwencji stają się odpowiedzialni za budowę i wdrożenie do praktyki funkcjonowania organizacji zintegrowanego systemu zarządzania wiedzą [Morawski 2010, s. 545]. Współcześnie zarówno menedżerowie, jak i pracownicy wykorzystują w swojej pracy pewien poziom wiedzy. Tworząc zaś różne sektory, takie jak zarządzanie, medycyna i opieka zdrowotna, operacje biznesowe i finansowe, prawo, edukacja, szkolenia i inne, sprawiają, że w najbliższej przyszłości należy spodziewać się dalszego ich wzrostu [Davenport 2007, s. 18-19], co staje się przyczynkiem do kształtowania nowych ról w organizacji przyszłości.

\section{Kształtowanie się nowych ról i umiejętności kierowniczych w perspektywie jutra}

W związku z dalszym rozwojem gospodarki opartej na wiedzy, która jest katalizatorem dla znaczącego udziału pracowników wiedzy w strukturze społeczeństwa, szczególne miejsce w tym zakresie przypada menedżerom. Muszą oni nauczyć się, jak zarządzać takimi pracownikami, odchodząc od rozkazywania na rzecz zaangażowania i pracy zespołowej. Muszą również poznać nowe metody oceniania niematerialnych wyników pracy, zmniejszyć biurokrację $\mathrm{i}$ formalizację pracy $\mathrm{w}$ organizacji oraz skoncentrować się na doborze i zatrzymaniu w organizacji najbardziej wartościowych i utalentowanych pracowników [Tomys 2009, s. 105]. Rola menedżera wiedzy będzie zatem wymagała zwiększonych wysiłków intelektualnych, polegających w głównej mierze na koncentracji zasobów niematerialnych, ich dalszego rozwoju poprzez tworzenie i dzielenie się wiedzą oraz budowę kultury organizacyjnej sprzyjającej uczeniu się.

Także zdaniem K. Perechudy $w$ organizacjach przyszłości, w szczególności z sektora high-technology, preferowanymi rolami menedżerów i pracowników, obok prezentowanej wyżej roli menedżera wiedzy, staną się jego odmiany, do których m.in. należą: organizator wiedzy, projektant wiedzy, agent wiedzy, wojownik wiedzy, kapłan wiedzy itd. [Perechuda 2009, s. 146]. Wypełnianie określonej roli będzie przede wszystkim uzależnione od rodzaju modelu zarządzania preferowanego zarówno w sektorze, jak i korporacji [Perechuda 2009, s. 146], a także od rodzaju organizacji i jej procesów oraz charakteru jej funkcjonowania i realizacji zadań.

Stosunek do władzy organizacyjnej w organizacji jutra będzie taki jak współcześnie, charakteryzujący się nietrwałością i przechodniością. Jednakże wydaje się, że większy nacisk zostanie położony na zarządzanie oparte na wzajemnym zaufaniu, zwiększonej partycypacji pracowniczej 
oraz tymczasowości realizowanych ról w organizacjach. Wynika to, zdaniem M. Morawskiego, $\mathrm{z}$ nowych koncepcji stosowanych w najlepszych organizacjach, w myśl których stanowiska kierownicze nie są zarezerwowane dla wybranej grupy osób realizujących daną ścieżkę kariery zawodowej. Rola menedżera to przede wszystkim rola (zbiór ról), którą wykonuje się cyklicznie albo przejściowo w zależności od strategii przedsiębiorstwa, bieżących potrzeb i problemów do rozwiązania [Morawski 2010, s. 542]. Stały zakres funkcji i obowiązków zastępowany jest tymczasowością, mającą swoje podłoże w zwiększającej się elastyczności zasobów organizacyjnych i mobilności kadry kierowniczej, wynikającej przede wszystkim z jej indywidualnych i organizacyjnych uwarunkowań.

Ze względu na coraz częstsze zmienianie się procesu percepcji środowiska organizacyjnego przez menedżerów (dostrzeganie „kajdanów organizacji”) preferowane dotychczas takie narzędzia pracy, jak: samochód i telefon służbowy, laptop, wyjazdy integracyjne stają się „kula u nogi”. Wydaje się, że menedżerowie doceniać będą aspekty związane z jakością życia. Podobnie jak podwładni będą oni bardziej preferować te organizacje, które dbają o pracownika poprzez budowę specjalnych programów tzw. work-life-balance. W większym stopniu niż współcześnie menedżerowie poszukiwać zatem będą optymalnej równowagi między pracą zawodową a życiem osobistym. Wydaje się bowiem, że dzisiejsze pokolenie menedżerów 30+ i 40+ niezbyt chętnie chce uczestniczyć $\mathrm{w}$,wyścigu szczurów”. Wynika to $\mathrm{z}$ tego, że menedżerowie coraz mocniej cenią sobie możliwość godzenia kariery zawodowej z życiem rodzinnym [www.weblog.infopraca.pl]. Zaczynaja zdawać sobie także sprawę, że brak tej równowagi może doprowadzić jednostkę do chronicznego stresu, pracoholizmu i wypalenia zawodowego, co w konsekwencji zwiększa jej koszty funkcjonowania w środowisku organizacyjnym. Chociaż programy work-life-balance w organizacjach zyskały na popularności już na początku XXI w., to z pewnością W kontekście wzrastających wymagań i oczekiwań pod względem efektywności pracy jednostki będą one szczególnie pożądane przez organizacje przyszłości. Także coraz częściej zaczyna się je uwzględniać jako element rankingów pracodawców i zawsze zajmuja wysokie miejsce na liście wymagań dotyczących potencjalnego pracodawcy [www.pracujflexi.pl]. W tej sytuacji rolą menedżera będzie kreowanie przyjaznego środowiska organizacyjnego, ukierunkowanego przede wszystkim na satysfakcję i zadowolenie pracownika. Rola ta polegać będzie także na ustaleniu motywatorów poszczególnym pracownikom, ich preferowanych wartości oraz pomaganiu w określeniu 
identyfikacji balansu sfery osobistej i zawodowej. Do tej roli w pewien sposób nawiązuje następna. Związana jest ona, zdaniem Z. Janowskiej, z coraz częstszym występowaniem wrażliwości odpowiedzialności społecznej menedżera za losy swoich podwładnych i wspomagania ich w trudnych dla nich sytuacjach zawodowych i osobistych. Jest to rola kreatora bezpieczeństwa pracy i promocji zdrowia [Janowska 2010, s. 211]. Coraz częściej menedżerowie chcąc uczynić pracowników bardziej usatysfakcjonowanymi $\mathrm{z}$ pracy, dbać będą o ich właściwe środowisko organizacyjne pod względem fizycznym oraz o treść i istote pracy. Środowisko to będzie zgodne $z$ wymaganiami i oczekiwaniami jednostki w miejscu pracy oraz będzie stwarzało optymalne warunki dla funkcjonowania pracowników. Takie zabiegi dokonywane przez menedżerów będą wpływały na pracowników w wymiarze indywidualnym (wzrost poczucia zadowolenia) oraz organizacyjnym (wydajność jednostki).

Pracownicy doceniając zatem range jakości życia w sytuacji pracy, będą oczekiwali również od menedżera większego wsparcia społecznego. Związane jest to $\mathrm{z}$ występowaniem sytuacji kryzysowych i stresowych, które mogą występować niezależnie od sytuacji trudnej, kształtowane zarówno w rozwoju psychospołecznym człowieka, jak i cyklu jego życia zawodowego [Januszkiewicz 2006, s. 37]. Dlatego, mając na uwadze zwiększające się zakresy i tempo pracy oraz możliwość przejawiania zjawisk patologicznych przez jednostkę, takich jak np. częsta absencja czy niski poziom zaangażowania organizacyjnego, należy stwierdzić, że w przyszłości najważniejszą rolą menedżera będzie counselling pracowniczy. Jest to ,specyficzny rodzaj wsparcia psychicznego, który pomaga pracownikowi przezwyciężyć problemy natury osobistej, a także pozwala na odkrywanie nowych możliwości, lepsze dopasowanie do kultury i klimatu organizacji, powodując w rezultacie zwiększanie jego efektywności" [Minter, Thomas 2000, cyt. za: Ziębicki 2007, s. 53]. Rolą menedżera w tym zakresie będzie udzielanie porad, wsparcia w zakresie psychologiczno-terapeutycznym, polegające na uzyskaniu szczegółowych informacji od pracownika na temat przyczyn zaistniałej sytuacji oraz możliwości „odblokowania” go, co pozwoli na dotarcie do rzeczywistych problemów [Ziębicki 2007, s. 54]. Wydaje się, że udzielane wsparcie społeczne przez menedżerów będzie wykazywało tendencję wzrostowa, zwłaszcza na tle kryzysu światowego przenikającego we wszystkie obszary funkcjonowania organizacji.

Z drugiej jednak strony, we współczesnych organizacjach, choć elastyczne zatrudnienie jest już teraz popularną formą na rynku pracy, 
w przyszłości zapewne zwiększać się będzie ranga menedżerów czasowników, zatrudnionych na określony czas. Zjawisko to będzie się pogłębiało, a o sukcesie menedżera przyszłości będzie świadczyć nie etat menedżerski czy kontrakt, a wybór pracy związany z czasem i miejscem pracy. Wynikać będzie to z dużej władzy eksperckiej menedżera, opartej na unikatowych kompetencjach i kwalifikacjach. Trzeba jednak zauważyć, że owa czasowość ról kierowniczych ma już miejsce obecnie. Pracownik może zatem zacząć kierować zespołem powołanym do realizacji określonego projektu i po zakończeniu zadania powraca na swoje dotychczasowe stanowisko. Ów brak etatowości powiązany będzie także $\mathrm{z}$ wynagrodzeniem za pracę, które będzie przede wszystkim wynagrodzeniem opartym na rzeczywistych kompetencjach menedżera.

Siłą menedżera jutra, podobnie jak menedżera współczesnego, jest także dalsza umiejętność działania w wielokulturowym otoczeniu, dzielenia się władzą, aktywizowania podwładnych do wspólnych zadań, umiejętność angażowania pracowników, zachęcania ich do przejmowania odpowiedzialności przywódczej we wszystkich sferach działania [Schein 1997, cyt. za: Janowska 2010, s. 193]. Odpowiedzialność i etyka menedżera będzie także szczególnie pożądaną treścią roli menedżera. Zdaniem A. Paliwody-Matiolańskiej jednostka oprócz posiadanego kodeksu moralnego, czyli systemu wartości wyznawanego, podlega również innym kodeksom, które nakładają na nią dodatkową odpowiedzialność. Należą do nich m.in.: odpowiedzialność w stosunku do swego pracodawcy, organizacji, innych pracowników, instytucji państwowych i społeczeństwa [Paliwoda-Matiolańska 2009, s. 95-96].

Decyzje podejmowane przez menedżera będą musiały uwzględniać wszystkie wymiary ponoszonej odpowiedzialności, co skutkować będzie jego zwiększoną wrażliwością etyczną i empatią społeczną. Odpowiada to także kreowaniu organizacji odpowiedzialnej społecznie uzyskującej maksymalne efekty ekonomiczne i przewage konkurencyjną przy jednoczesnym poszanowaniu wartości etycznych w sytuacji pracy menedżera.

Rozwój technologii informacyjnych i gospodarki opartej na wiedzy sprawia, że pracownicy coraz częściej wykonują swoje zadania poza miejscem organizacji. Ta forma pracy, nazywana telepraca, sprawia, że od kadry menedżerskiej będzie wymagać się nowych umiejętności. W tym aspekcie konstytuuje się zatem nowa rola - menedżera wirtualnego, dla którego wyzwaniem będzie przede wszystkim motywowanie pracowników na odległość, utrzymywanie sieci komunikacyjnych, zarządzanie zespołami w przestrzeni wirtualnej, a także tworzenie i wspieranie trwałej kultury, która umożliwia wydajna 
pracę, zaś jedyną niezawodną drogą rozwoju zawodowego będzie ciągłe podnoszenie kwalifikacji [Warner, Witzel 2005, s. 180-181]. Zmiany w strukturze zatrudnienia, dalszy rozwój technologiczny i umocnienie telepracy w kodeksie pracy poprzez określenie praw i obowiązków telepracownika sprawi, że telepraca będzie zyskiwać dużą popularność na rynku pracy, co w konsekwencji przyczyni się do tego, że menedżerowie wirtualni będą w organizacji „zjawiskiem coraz powszechniejszym” [Warner, Witzel 2005, s. 168].

Coraz częściej organizacje zmuszone są do podjęcia nieprzewidzianych działań wywołanych zjawiskami kryzysowymi. W tej sytuacji szczególna rola przypada naczelnemu kierownictwu, gdyż na tym szczeblu zarządzania istnieje największa możliwość identyfikacji źródeł kryzysowych w organizacji oraz generowania decyzji o charakterze antykryzysowym [Skalik 2004, s. 149]. Od niej zależy także, czy organizacja przetrwa kryzys mogący być okazją do jej odnowy. Opanowanie kryzysu i przejście do pozytywnej odnowy organizacji wymagać będzie od menedżerów specyficznych ról, do których należeć będzie menedżer kryzysowy i menedżer odnowy [por. Bednarska-Wnuk 2010].

Pierwszy z nich, menedżer kryzysowy ma zapewnić organizacji nie tylko sprawne funkcjonowanie i jej rozwój, ale także sposób opanowania i przetrwania występującego kryzysu. Charakteryzuje się on defensywną postawą, jest skoncentrowany na uzdrowieniu i odnowie przedsiębiorstwa w stosunkowo krótkim czasie [Zelek 2003, s. 201]. Menedżer kryzysowy zdaniem J. Skalika jest przede wszystkim odpowiedzialny za dobór i realizację strategii, systematyczną i wnikliwą ocenę sytuacji panującej w otoczeniu i generowanie takich decyzji, które korygują zachowania $\mathrm{w}$ organizacji [Skalik 2004, s. 149]. Jeśli doprowadzi organizację do odnowy, wydaje się, że jego rola powinna się przekształcić w rolę menedżera odnowy. Osoba taka przywraca i odtwarza pozytywny wizerunek organizacji sprzed sytuacji kryzysowej. Głównym zaś celem menedżera odnowy jest zorientowanie na działania związane $\mathrm{z}$ odnową organizacji. Może ona przyjmować dwa kierunki: proces rewitalizacji, polegający na wykorzystaniu w większym stopniu posiadanych kluczowych zasobów i kompetencji oraz koncentracja na wymaganiach otoczenia poprzez rekonstrukcję i zwrot ku kluczowym kompetencjom, realizowanych $\mathrm{w}$ fazie cyklu życia dojrzałości organizacji [Pascale 1999, cyt. za: Banaszyk, Cyfert 2007, s. 13]. Chociaż niektóre zadania menedżera odnowy przypisywane są menedżerom kryzysowym, np. interwencja pokryzysowa [Zelek 2003, s. 200], to wydaje się, że powinno dokonać się takiego rozgraniczenia. Menedżer odnowy 
powinien być przede wszystkim odpowiedzialny za „przesunięcie” zasobów ludzkich tam, gdzie są aktualnie najbardziej potrzebne i gdzie można wykorzystać ich kompetencje w sposób maksymalny. Jego zadaniem jest właśnie interwencja kryzysowa, czyli działanie na rzecz przywrócenia normalnego trybu funkcjonowania organizacji, usuwanie skutków kryzysu, zamknięcie - sprawozdanie ze skutków kryzysu oraz wykorzystanie doświadczeń $\mathrm{w}$ celu zabezpieczenia przyszłości [Zelek 2003, s. 200]. Rolą menedżera odnowy, wydaje się, będzie także umiejętność szukania nowych partnerów strategicznych, zapewniających uzyskanie bądź przywrócenie dawnej przewagi konkurencyjnej. Rola menedżera kryzysu i odnowy będzie zatem szczególnym wyzwaniem dla menedżerów jutra. Ich ranga, jak również wszystkich ról omówionych powyżej, będzie wzrastać wobec nieprzewidywalności środowiska organizacji.

\section{Wnioski i uwagi końcowe}

Podsumowując powyższe rozważania, należy stwierdzić, iż w literaturze istnieje wiele klasyfikacji i propozycji podziału tradycyjnych i współczesnych ról kierowniczych oraz zbioru nowych wymagań stawianym menedżerom. Odnoszą się one nie tylko do zróżnicowanego katalogu ról, ale również konstytuują się w zależności od poziomu zarządzania czy rodzaju stanowiska (funkcjonalnego lub liniowego). Zaprezentowane powyżej typy ról kierowniczych $\mathrm{z}$ perspektywy organizacji tradycyjnej i współczesnej miały na celu wyeksponować te, które są najczęściej akcentowane w literaturze przedmiotu. Odnoszone zaś do organizacji jutra określono na podstawie nie tylko występujących, ale również dopiero zarysowujących się trendów w gospodarce opartej na wiedzy. Dokonaną w pracy charakterystykę można zatem uznać za pewną reprezentatywną próbę opisu ról kierowniczych $\mathrm{w}$ organizacji. Biorąc natomiast pod uwagę ich integrację, poniżej przedstawiono role, grupując według charakterystycznych, podstawowych elementów opisujących je.

Tabela 1. Menedżer w organizacji tradycyjnej, współczesnej i jutra

\begin{tabular}{|c|l|l|l|}
\hline $\begin{array}{c}\text { Charakterysty- } \\
\text { ka elementów } \\
\text { treści roli } \\
\text { i umiejętności }\end{array}$ & \multicolumn{3}{|c|}{ Menedżer } \\
\cline { 2 - 4 } & Tradycyjny & Współczesny & \multicolumn{1}{|c|}{ Jutra } \\
\hline $\begin{array}{c}\text { Stosunek do } \\
\text { podwładnych }\end{array}$ & $\begin{array}{l}\text { - przełożony } \\
\text { w centrum } \\
\text { działania, } \\
\text { - mechanistyczne }\end{array}$ & $\begin{array}{l}\text { - dostrzeganie pote- } \\
\text { ncjału jednostki, } \\
\text { - zachęcanie } \\
\text { podwładnego do }\end{array}$ & $\begin{array}{l}\text { - zespołowe podejmo- } \\
\text { wanie decyzji, } \\
\text { - ,dawanie” wsparcia } \\
\text { społecznego, }\end{array}$ \\
\hline
\end{tabular}




\begin{tabular}{|c|c|c|c|}
\hline & $\begin{array}{l}\text { podejście do } \\
\text { podwładnego, } \\
\text { - „środek” do } \\
\text { realizacji celów } \\
\text { i zadań } \\
\text { organizacyjnych } \\
\text { - decyzje } \\
\text { „narzucane” } \\
\text { odgórnie }\end{array}$ & $\begin{array}{l}\text { angażowania } \\
\text { organizacyjnego, } \\
\text { - relacje oparte na } \\
\text { obopólnym } \\
\text { zaufaniu, } \\
\text { - decyzje } \\
\text { konsultowane } \\
\text { z pracownikami }\end{array}$ & $\begin{array}{l}\text { - aktywizacja } \\
\text { podwładnych do } \\
\text { wspólnych zadań, } \\
\text { - angażowanie } \\
\text { pracowników do } \\
\text { przejmowania } \\
\text { odpowiedzialności } \\
\text { przywódczej, } \\
\text { - kreowanie przyja- } \\
\text { znego środowiska } \\
\text { organizacyjnego } \\
\text { ukierunkowanego na } \\
\text { satysfakcję i zadowo- } \\
\text { lenie pracowników }\end{array}$ \\
\hline $\begin{array}{l}\text { Dominujące } \\
\text { umiejętności }\end{array}$ & $\begin{array}{l}\text { - } \\
\text { selekcjonowania } \\
\text { informacji, } \\
\text { - organizowania } \\
\text { pracy podwła- } \\
\text { dnym, } \\
\text { - egzekwowania } \\
\text { wydanych pole- } \\
\text { ceń, } \\
\text { - redukcja niepe- } \\
\text { wności wśród } \\
\text { pracowników }\end{array}$ & $\begin{array}{l}\text { - spajanie } \\
\text { wszystkich } \\
\text { elementów (ludzi } \\
\text { i działań), } \\
\text { - kreowanie środo- } \\
\text { wiska sprzyjającego } \\
\text { pracy opartej na } \\
\text { wiedzy, } \\
\text { - samodzielne } \\
\text { rozwiązywanie } \\
\text { złożonych, } \\
\text { nierutynowych } \\
\text { problemów, } \\
\text { - umiejętność } \\
\text { kierowania własnym } \\
\text { rozwojem } \\
\text { zawodowym } \\
\text { i pracownika } \\
\text { - wyzwalanie } \\
\text { kreatywności } \\
\text { i otwartości na } \\
\text { przyszłe wyzwania, } \\
\text { - umiejętność dzie- } \\
\text { lenia się wiedzą, } \\
\text { - umiejętność budo- } \\
\text { wy kultury organi- } \\
\text { zacyjnej sprzyjającej } \\
\text { uczeniu się, } \\
\text { - permanentna goto- } \\
\text { wość do uczenia się, } \\
\text { - umiejętność zarzą- } \\
\text { dzania heterogeni- } \\
\text { cznym personelem } \\
\text { w środowisku } \\
\text { wielokulturowym, }\end{array}$ & $\begin{array}{l}\text { - umiejętność pracy } \\
\text { w zespołach } \\
\text { międzynarodowych, } \\
\text { - umiejętność } \\
\text { zarządzania } \\
\text { heterogenicznym } \\
\text { personelem } \\
\text { w środowisku wielo- } \\
\text { kulturowym, } \\
\text { - umiejętność } \\
\text { funkcjonowania } \\
\text { w różnorodnym } \\
\text { otoczeniu, } \\
\text { - umiejętność budowy } \\
\text { kultury organizacyjnej } \\
\text { sprzyjającej uczeniu się, } \\
\text { - umiejętność dzielenia } \\
\text { się wiedzą, } \\
\text { - umiejętność szukania } \\
\text { nowych parterów } \\
\text { strategicznych } \\
\text { zapewniających } \\
\text { uzyskanie bądź } \\
\text { przywrócenie dawnej } \\
\text { przewagi } \\
\text { konkurencyjnej, } \\
\text { - umiejętność } \\
\text { zapewnienia optymalnej } \\
\text { równowagi między } \\
\text { pracą a życiem } \\
\text { zawodowym (własnej i } \\
\text { pracowników) }\end{array}$ \\
\hline
\end{tabular}




\begin{tabular}{|c|c|c|c|}
\hline & & $\begin{array}{l}\text { - umiejętność } \\
\text { funkcjonowania } \\
\text { w różnorodnym } \\
\text { otoczeniu }\end{array}$ & \\
\hline $\begin{array}{l}\text { Dominujące } \\
\text { role }\end{array}$ & $\begin{array}{l}\text { - dyrektora, } \\
\text { - nakazującego, } \\
\text { - nadzorcy, } \\
\text { - kontrolera }\end{array}$ & $\begin{array}{l}\text { - architekt procesów } \\
\text { organizacyjnych, } \\
\text { - agent zmiany, } \\
\text { - przywódca, } \\
\text { - e-menedżer, } \\
\text { - coach, } \\
\text { - mentor, } \\
\text { - przedsiębiorca, } \\
\text { - profesjonalista, } \\
\text { - inicjator i } \\
\text { propagator kluczo- } \\
\text { wych wartości } \\
\text { organizacyjnych, } \\
\text { - menedżer } \\
\text { międzynarodowy, } \\
\text { - menedżer wiedzy }\end{array}$ & $\begin{array}{l}\text { - menedżer wiedzy } \\
\text { (organizator, proje- } \\
\text { ktant, agent, wojo-wnik, } \\
\text { kapłan wiedzy), } \\
\text { - kreator } \\
\text { bezpieczeństwa pracy i } \\
\text { promocji zdrowia, } \\
\text { - kreator organizacji } \\
\text { odpowiedzialnej } \\
\text { społecznie, } \\
\text { - counselling } \\
\text { pracowniczy, } \\
\text { - menedżer wirtualny, } \\
\text { - menedżer kryzysowy, } \\
\text { - menedżer odnowy }\end{array}$ \\
\hline Dystans władzy & $\begin{array}{l}\text { duży } \\
\text { (asymetryczna } \\
\text { koncepcja } \\
\text { władzy) }\end{array}$ & $\begin{array}{l}\text { mały } \\
\text { (nietrwałość, } \\
\text { przechodniość, } \\
\text { empowerment) }\end{array}$ & $\begin{array}{l}\text { mały bądź brak } \\
\text { (,zacieranie się” granic } \\
\text { między przełożonym } \\
\text { a podwładnym) }\end{array}$ \\
\hline $\begin{array}{l}\text { Horyzont } \\
\text { czasowy } \\
\text { pełnienia ról } \\
\text { kierowniczych }\end{array}$ & stały & stały i tymczasowy & $\begin{array}{l}\text { przede wszystkim } \\
\text { tymczasowy }\end{array}$ \\
\hline $\begin{array}{l}\text { Preferowany } \\
\text { typ człowieka - } \\
\text { menedżera } \\
\text { w organizacji } \\
\text { (na podstawie: Stor } \\
\text { 2010, s. } 709 \text { ) }\end{array}$ & $\begin{array}{l}\text { Homo } \\
\text { oeconomicus }\end{array}$ & $\begin{array}{l}\text { Homo diversicus } \\
\text { Homo creativus } \\
\text { Homo cognitionis } \\
\text { (człowiek wiedzy) }\end{array}$ & $\begin{array}{l}\text { Homo cognitionis } \\
\text { (człowiek wiedzy) } \\
\text { Homo rectum } \\
\text { (człowiek wirtualny) } \\
\text { E-homo }\end{array}$ \\
\hline $\begin{array}{l}\text { Styl kierowania } \\
\text { i podejmowania } \\
\text { decyzji }\end{array}$ & autokratyczny & demokratyczny & demokratyczny \\
\hline
\end{tabular}

Źródło: Opracowanie własne na podstawie literatury wskazanej w opracowaniu.

Przedstawiona charakterystyka menedżera organizacji tradycyjnej, współczesnej i jutra jest pewnym zabiegiem merytorycznym, pokazującym sposób ewolucji wypełnianych przez niego ról 
w organizacji. O ile jednak role menedżera $\mathrm{w}$ organizacji tradycyjnej i współczesnej są dość mocno osadzone w literaturze, o tyle stosunkowo mało jest opracowań wskazujących na wymagania i oczekiwania względem menedżerów jutra. Takie spojrzenie jest jednak konieczne i potrzebne ze względu na dokonywany nieustający proces zmian w organizacjach. Menedżer znając podstawową charakterystykę elementów treści roli i umiejętności menedżera jutra, będzie mógł łatwiej „wejść w nowe role”, zwłaszcza wobec wyzwań przyszłości.

\section{Bibliografia}

1. Akella D., Changes in Managerial Work: Tech Managers Dotcom, "Global Business Review” 2006, Vol. 7, Issue 2.

2. Almashaqba Z.M.S., Nemer Al-Qeed M. A., The Classical Theory of Organisation and it's Relevance, "International Research Journal of Finance \& Economics" 2010, Issue 41.

3. Banaszyk P., Cyfert Sz., Strategiczna odnowa przedsiębiorstwa, Difin, Warszawa 2007.

4. Bednarska-Wnuk I., Rola kadry kierowniczej w warunkach kryzysu i odnowy, w: J. Skalik (red.), Zmiana warunkiem sukcesu. Odnowa przedsiębiorstw - czego nauczyt nas kryzys, Prace Naukowe Uniwersytetu Ekonomicznego we Wrocławiu nr 128, Wrocław 2010.

5. Bieda J., Menedżer $w$ perspektywie jutra, Śląska Wyższa Szkoła Zarządzania im. gen. Jerzego Ziętka w Katowicach, Katowice 2004.

6. Błaszczyk W., Kadra kierownicza polskich przedsiębiorstw państwowych w warunkach zmian systemu gospodarczego, Wydawnictwo Uniwersytetu Łódzkiego, Łódź 1999.

7. Błaszczyk W., Kreatywność i przedsiębiorczość jako cechy współczesnego menedzera, w: T. Listwan (red.), Sukces w zarzadzaniu kadrami. Perspektywa globalna $i$ lokalna, Prace Naukowe Akademii Ekonomicznej we Wrocławiu, Wrocław 2004.

8. Bradford D. L., Cohen A. R., Managing for Excellence, Wiley Publications, New York 1984.

9. Charbonnier-Voirin A., El Akremi A., L'effet de l'habilitation sur la performance adaptative des employés, "Relations Industrielles / Industria Relations" 2011, Vol. 66, Issue 1.

10. Davenport T. H., Zarzadzanie pracownikami wiedzy, Wolters Kluwer business, Kraków 2007.

11. Dąbek M., Menedżerowie okresu transformacji: problemy, potencjat, rozwój, Wydawnictwo Uniwersytetu Wrocławskiego, Wrocław 2002.

12. Desmarais C., Abord de Chatillon E., Le rôle de traduction du manager, Entre allégeance et résistance, "Revue française de gestion" 2010, No. 205.

13. Dumaine B., The New Non-Manager, "Fortune" 1993 February 22, Vol. 127, Issue 4.

14. Griffin R., Podstawy zarzqdzania organizacjami, Wydawnictwo Naukowe PWN, Warszawa 2004.

15. Ehrich L. C., Hansford B., Mentoring: Pros and Cons for HRM, "Asia Pacific Journal of Human Resources" 1997, Vol. 37, No. 3. 
16. Evans Ch., Zarzadzanie wiedza, PWE, Warszawa 2005.

17. Fazlagić A., Gospodarka wiedzy - tam właśnie zmierzamy, wkładka Zarządzanie Wiedzą, „Poradnik Gazety Prawnej” 2001, Nr 34.

18. Grudzewski W. M., Hejduk I. K., Sankowska A., Wańtuchowicz M., Sustainability $w$ biznesie czyli przedsiębiorstwo przyszłości. Zmiana paradygmatów $i$ koncepcji zarzadzania, Poltext, Warszawa 2010.

19. Hezlett S. A., Gibson S. K., Linking Mentoring and Social Capital: Implications for Career and Organization Development, "Advances in Developing Human Resources", August 2007, Vol. 9, No. 3.

20. Hezlett S. A., Gibson S. K., Mentoring and Human Resource Development: Where We Are and Where We Need to Go, "Advances in Developing Human Resources", November 2005, Vol. 7, No. 4.

21. Hon A. H. Y., Bloom M., Crant J. M., Overcoming Resistance to Change and Enhancing Creative Performance, "Journal of Management" 2011, Vol. 20, No. 10.

22. Katz R. L., Skills of an Effective Administrator, "Harvard Business Review", January-February 1955.

23. Janowska Z., Zarzqdzanie zasobami ludzkimi, PWE, Warszawa 2010.

24. Januszkiewicz K., Praca jako istotny obszar ksztattowania jakości życia, w: W. Błaszczyk, K. Januszkiewicz, J. Śmigielski (red.), Oblicza jakości życia. Człowiek w sytuacji pracy, Wydawnictwo Uniwersytetu Łódzkiego, Łódź 2006.

25. Kaczmarek B., Sikorski Cz., Podstawy zarzadzania. Zachowania organizacyjne, Wydawnictwo Uniwersytetu Łódzkiego, Łódź 1999.

26. Kieżun W., Sprawne zarzqdzanie organizacja. Zarys teorii i praktyki, Szkoła Główna Handlowa, Warszawa 1997.

27. Koźmiński A. K., Technokraci i humaniści. Dwa spojrzenia na ludzka pracę, Wydawnictwo Iskry, Warszawa 1977.

28. Listwan T., Stor M., Zarzqdzanie kadra menedżerska $w$ organizacjach międzynarodowych $w$ Polsce, Wydawnictwo Uniwersytetu Ekonomicznego we Wrocławiu, Wrocław 2008.

29. Mládková L., Management of Knowledge Workers, "Economics \& Management" 2011, Vol. 16.

30. Morawski M., Menedżerowie procesów zarządzania wiedzq. Zarys kompetencji, w: T. Listwan, S. T. Witkowski (red.), Menedżer $w$ gospodarce opartej na wiedzy, Prace Naukowe Uniwersytetu Ekonomicznego we Wrocławiu nr 115, Wydawnictwo Uniwersytetu Ekonomicznego we Wrocławiu, Wrocław 2010.

31. Morawski M., Zarzqdzanie profesjonalistami, PWE, Warszawa 2009.

32. Paliwoda-Matiolańska A., Odpowiedzialność społeczna $w$ procesie zarzadzania, C.H. Beck, Warszawa 2009.

33. Penc J., Role $i$ umiejętności menedżerskie. Sekrety sukcesu i kariery, Difin, Warszawa 2005.

34. Perechuda K., Wiodace umiejętności menedżerów wiedzy, w: T. Kupczyk (red.), Uwarunkowania sukcesów kadry kierowniczej w gospodarce opartej na wiedzy, Difin, Warszawa 2009.

35. Potrzeba work-life balance wynikiem dzieciństwa pracownika (2011), http://weblog.infopraca.pl/2011/06/potrzeba-work-life-balance-wynikiemdziecinstwa-pracownikow/ (dostęp 18.08.11).

36. Pracodawcy płaca za szkolenia, http://www.hrtrendy.pl/2011/04/18/pracodawcyplaca-za-szkolenia/ (dostęp 18.08.11). 
37. Rakowska A., Kompetencje menedżerskie kadry kierowniczej we współczesnych organizacjach, Wydawnictwo Uniwersytetu Marie Curie Skłodowskiej, Lublin 2007.

38. Schermerhorn J. R. Jr., Zarzadzanie. Kluczowe koncepcje, PWE, Warszawa 2008.

39. Segers J., Vloeberghs D., Henderickx E., Inceoglu I., Structuring and Understanding the Coaching Industry: The Coaching Cube, "Academy of Management Learning and Education" 2011, Vol. 10, No. 2.

40. Sikorski Cz., Nauka o zarzqdzaniu, Wydawnictwo Akademii Humanistyczno-Ekonomicznej w Łodzi, Łódź 2009.

41. Sikorski Cz., Profesjonalizm. Filozofia zarzqdzania nowoczesnym przedsiębiorstwem, PWN, Warszawa 1995.

42. Sikorski Cz., Zachowania ludzi w organizacji, Wydawnictwo Naukowe PWN, Warszawa 1999.

43. Skalik J., Kierownik w sytuacji kryzysowej, w: T. Listwan (red.), Sukces w zarzqdzaniu kadrami. Perspektywa globalna i lokalna, Prace Naukowe Akademii Ekonomicznej we Wrocławiu, Wrocław 2004.

44. Stańczyk-Hugiet E., Czy ekonomia wiedzy powoduje zmianę roli menedíera? w: T. Listwan, S. T. Witkowski (red.), Menedżer w gospodarce opartej na wiedzy, Prace Naukowe Uniwersytetu Ekonomicznego we Wrocławiu nr 115, Wydawnictwo Uniwersytetu Ekonomicznego we Wrocławiu, Wrocław 2010.

45. Stor M., Kwalifikacje $i$ kompetencje kadry menedzerskiej korporacji międzynarodowej $w$ gospodarce opartej na wiedzy, w: T. Listwan, S. T. Witkowski (red.), Menedżer w gospodarce opartej na wiedzy, Prace Naukowe Uniwersytetu Ekonomicznego we Wrocławiu nr 115, Wydawnictwo Uniwersytetu Ekonomicznego we Wrocławiu, Wrocław 2010.

46. Stosik A., Ewolucja ról menedżerskich $w$ organizacjach entrepreneurskich, w: J. Skalik (red.), Zmiana warunkiem sukcesu. Przeobrażenia metod i praktyk zarzqdzania, Wydawnictwo Akademii Ekonomicznej we Wrocławiu, Wrocław 2005.

47. Szaban J., Przemiany roli polskich dyrektorów $w$ wyniku zmian ustrojowych. Od dyrektora do euromenedżera, Wydawnictwo Wyższej Szkoły Przedsiębiorczości i Zarządzania im. Leona Koźmińskiego, Warszawa 2000.

48. Świątek-Barylska I., Menedżer $w$ roli inicjatora i propagatora kluczowych wartości organizacyjnych, w: T. Listwan, S. T. Witkowski (red.), Menedżer w gospodarce opartej na wiedzy, Prace Naukowe Uniwersytetu Ekonomicznego we Wrocławiu nr 115, Wydawnictwo Uniwersytetu Ekonomicznego we Wrocławiu, Wrocław 2010.

49. Taylor F. W., Zasady naukowego zarzqdzania, w: J. Kurnal (red.), Twórcy naukowych podstaw organizacji. Wybór pism, PWE, Warszawa 1972.

50. Tomys M., Kierunki i zakres zmian $w$ zarzadzaniu zasobami ludzkimi $w$ organizacji opartej na wiedzy, w: T. Kupczyk (red.), Uwarunkowania sukcesów kadry kierowniczej w gospodarce opartej na wiedzy, Difin, Warszawa 2009.

51. Warner M., Witzel M., Zarzqdzanie organizacja wirtualnq, Oficyna Ekonomiczna, Kraków 2005.

52. Westover J. H., Managing Organizational Change: Change Agent Strategies and Techniques to Successfully Managing the Dynamics of Stability and Change in Organizations, "International Journal of Management and Innovation” 2010, Vol. 2, Issue 1.

53. Zając Cz., Zarzqdzanie poprzez wartości jako czynnik sukcesu współczesnego przedsiębiorstwa, w: M. Czerska, H. Czubasiewicz (red.), Społeczne 
uwarunkowania sukcesu organizacji, Prace i Materiały Wydziału Zarządzania Uniwersytetu Gdańskiego, t. 2, Gdańsk 2009.

54. Zelek A., Zarzqdzanie kryzysem $w$ przedsiębiorstwie. Perspektywa strategiczna, Instytut Organizacji i Zarządzania w Przemyśle „Orgmasz”, Warszawa 2003.

55. Zieleniewski J., Organizacja i zarzqdzanie, PWN, Warszawa 1976.

56. Ziębicki B., Nowoczesne metody doskonalenia kompetencji pracowniczych, w: J. Czekaj (red.), Metody organizacji $i$ zarzqdzania, Wydawnictwo Akademii Ekonomicznej w Krakowie, Kraków 2007.

10 miejsc z najlepszym work-life balance (2011),

http://pracujflexi.pl/magazyn/index.php/2011/06/10-miejsc-z-najlepszym-work-lifebalance/ (dostęp 18.08.11).

\section{Spis tabel}

Tabela 1 Menedżer w organizacji tradycyjnej, współczesnej i jutra. 